\title{
Pasture uptake from solid and liquid applications of cobalt and copper sulphate
}

\author{
J.D. MORTON ${ }^{1}$ and L.C. SMITH \\ AgResearch Invermay, PB 50034, Mosgiel \\ ${ }^{1}$ Mortonj@agresearch.cri.nz
}

\begin{abstract}
Uptake of cobalt $(\mathrm{Co})$ and copper $(\mathrm{Cu})$ by ryegrasswhite clover based pasture was measured from December 1999 to March 2000 at Woodlands Research Station in Southland. Treatments were control, cobalt sulphate $\left(\mathrm{CoSO}_{4}\right)$ at 120 and $240 \mathrm{~g} / \mathrm{ha}$ initially and $60 \mathrm{~g} / \mathrm{ha}$ monthly, and copper sulphate $\left(\mathrm{CuSO}_{4}\right)$ at 5 and $10 \mathrm{~kg} / \mathrm{ha}$ initially and $1.25 \mathrm{~kg} / \mathrm{h}$ a monthly, applied in either solid or liquid forms. At $120 \mathrm{~g} \mathrm{CoSO}_{4} / \mathrm{ha}$ applied as solid and liquid, pasture Co content was significantly $(\mathrm{P}<0.05)$ elevated above control for up to 3 weeks after application. $\mathrm{CoSO}_{4}$ applied initially at $240 \mathrm{~g} / \mathrm{ha}$ in both forms significantly increased pasture Co above control for 6-7 weeks after application. For the December monthly application, neither solid or liquid application of $60 \mathrm{~g} \mathrm{CoSO}_{4} /$ ha significantly increased pasture Co from 2 weeks after application. Later applications resulted in both forms of $\mathrm{CoSO}_{4}$ significantly increasing pasture Co above control for up to 3 weeks after application. Pasture Co was significantly higher from liquid compared to solid application in February and March. When applied in one application, $5 \mathrm{~kg}$ solid $\mathrm{CuSO}_{4} /$ ha significantly increased pasture copper $(\mathrm{Cu})$ content above control for 3 weeks, $5 \mathrm{~kg}$ liquid $\mathrm{CuSO}_{4} /$ ha had an effect for 4 weeks, $10 \mathrm{~kg}$ solid $\mathrm{CuSO}_{4} /$ ha for 5 weeks, and $10 \mathrm{~kg}$ liquid $\mathrm{CuSO}_{4} /$ ha for 13 weeks. Monthly applications of $1.25 \mathrm{~kg} \mathrm{CuSO} /$ ha significantly increased pasture $\mathrm{Cu}$ above control for 1-2 weeks after application in all months. There was a significant increase in pasture $\mathrm{Cu}$ from liquid compared with solid application in February and March. The short duration of effect of the high rates of $\mathrm{CoSO}_{4}$ and $\mathrm{CuSO}_{4}$ suggest that, if required, they should be applied at a time when the animal can build up stores of $\mathrm{Co}$ and $\mathrm{Cu}$ in the liver before a critical period. In summer/autumn, when rainfall is lower, $\mathrm{CoSO}_{4}$ and $\mathrm{CuSO}_{4}$ if required, should be applied as liquid, 1 week before the pasture is grazed. These recommendations assume that the increase in pasture uptake of $\mathrm{Co}$ and $\mathrm{Cu}$ would result in greater $\mathrm{Co}$ and $\mathrm{Cu}$ availability to the animal.
\end{abstract}

Keywords: $\mathrm{CoSO}_{4}, \mathrm{CuSO}_{4}$, pasture, Co content, $\mathrm{Cu}$ content

\section{Introduction}

Deficiencies of mainly cobalt (Co) for sheep and copper $(\mathrm{Cu})$ for cattle and deer occur across a range of New Zealand soils. Traditionally, either application of cobalt sulphate $\left(\mathrm{CoSO}_{4}\right)$ and copper sulphate $\left(\mathrm{CuSO}_{4}\right)$ in fertiliser or treatment of animals has been used to overcome these deficiencies. More recently, $\mathrm{CoSO}_{4}$ has been mixed with water and sprayed on to pasture as a short-term treatment option to replace animal treatment. Earlier research (Sherrell 1990; Pringle et al. 2000) has measured higher pasture Co content from liquid compared with solid forms of $\mathrm{CoSO}_{4}$. The reported trial was carried out to gain further information on the effect of form and rate of $\mathrm{CoSO}_{4}$ on pasture $\mathrm{Co}$, and to investigate the effect of form and rate of $\mathrm{CuSO}_{4}$ on pasture $\mathrm{Cu}$ content. The effect of form of $\mathrm{CuSO}_{4}$ has not been previously researched in New Zealand.

\section{Materials and methods}

\section{Site and treatments}

The trial was sited on a 6-year-old pasture originally sown with ryegass and white clover but now also containing other grasses and flatweeds, on a Waikiwi brown soil at Woodlands Research Station near Invercargill. Initial, EDTA-extractable, soil Co was $1.55 \mathrm{ppm}$, soil $\mathrm{Cu} 2.95 \mathrm{ppm}$ and soil Mn $201 \mathrm{ppm}$. The $\mathrm{CoSO}_{4}$ and $\mathrm{CuSO}_{4}$ applied had over $90 \%$ of particles in the size range $0.15-0.5 \mathrm{~mm}$. When applied in the solid form, $\mathrm{CoSO}_{4}$ and $\mathrm{CuSO}_{4}$ were mixed with sand. In the liquid form they were mixed with sufficient water to cover the whole plot once and sprayed on to the pasture. Plot size was $15 \mathrm{~m}^{2}$ and there were 5 replicates of each treatment. The treatments were control, $\mathrm{CoSO}_{4}(120,240 \mathrm{~g} / \mathrm{ha})$ and $\mathrm{CuSO}_{4}(5,10 \mathrm{~kg} /$ ha) applied on $2 \mathrm{Dec} 1999$, and $\mathrm{CoSO}_{4}(60 \mathrm{~g} / \mathrm{ha})$ and $\mathrm{CuSO}_{4}(1.25 \mathrm{~kg} / \mathrm{ha})$ applied on 2 December 1999, 5 January, 3 February, and 3 March 2000.

\section{Measurements}

The once only December application plots were sampled weekly for the first 2 months and fortnightly thereafter. 
Plots with monthly applications and controls were sampled weekly from December to March. At each sampling, pasture was clipped from 20 sites in each plot down to sheep grazing height $(2-$ $3 \mathrm{~cm})$ and bulked. Each bulked sample was dried at $60^{\circ} \mathrm{C}$ for 24 hours and analysed for $\mathrm{Co}$ or $\mathrm{Cu}$ concentration using atomic absorption. Only samples from one replicate were analysed 1 week after the initial application because of a laboratory fire, so no statistical analysis could be carried out. The whole trial site was grazed by ewes for 12 hours every 4-6 weeks when pasture mass reached $2 \mathrm{t} \mathrm{DM/ha.} \mathrm{Daily} \mathrm{rainfall} \mathrm{was}$ measured during the trial.

\section{Results}

The effect of form and rate of $\mathrm{CoSO}_{4}$ and $\mathrm{CuSO}_{4}$ on pasture $\mathrm{Co}$ and $\mathrm{Cu}$ content is shown in Figures 1 and 2 respectively.

\section{Cobalt sulphate}

From the single December application, pasture Co from the solid and liquid form was significantly greater $(\mathrm{P}<0.05)$ than control at 3 weeks after application at $120 \mathrm{~g} /$ ha (Figure 1A). At $240 \mathrm{~g} / \mathrm{ha}$, both forms resulted in significantly greater pasture Co than control for 6-7 weeks after application (Figure 1B). There were no significant differences in pasture Co between forms at either rate.

With the monthly application of $60 \mathrm{~g}$ $\mathrm{CoSO}_{4} / \mathrm{ha}$, there was a trend for pasture Co from both forms to increase significantly above control for up to 2 weeks after application and then decline (Figure 1C). Pasture Co from liquid $\mathrm{CoSO}_{4}$ was significantly greater than from solid $\mathrm{CoSO}_{4}$ for 1-2 weeks after the February and March applications.

\section{Copper sulphate}

From the single December application of $\mathrm{CuSO}_{4}$, at $5 \mathrm{~kg} / \mathrm{ha}$, the solid form significantly increased pasture $\mathrm{Cu}$ content above control for 3 weeks and the solid form for 4 weeks (Figure 2A). At $10 \mathrm{~kg} / \mathrm{ha}$, corresponding values were 5 weeks for solid and 13 weeks for liquid $\mathrm{CuSO}_{4}$ (Figure 2B). Liquid application resulted in significantly greater pasture $\mathrm{Cu}$ than solid application for 5 weeks at $5 \mathrm{~kg} / \mathrm{ha}$ and 7 weeks at $10 \mathrm{~kg} / \mathrm{ha}$.

For monthly applications of $1.25 \mathrm{~kg} \mathrm{CuSO}_{4}$, there was a similar cyclical pattern to $\mathrm{CoSO}_{4}$ (Figure 2C). The liquid but not the solid form resulted in a significant
Effect of solid and liquid forms of $\mathrm{CoSO}_{4}$ on pasture Co content for (A) $120 \mathrm{~g} / \mathrm{ha}$ applied once, (B) $240 \mathrm{~g} / \mathrm{ha}$ applied once and (C) $60 \mathrm{~g} / \mathrm{ha}$ applied monthly. Bars are LSD (5\%). Arrows indicate application dates.
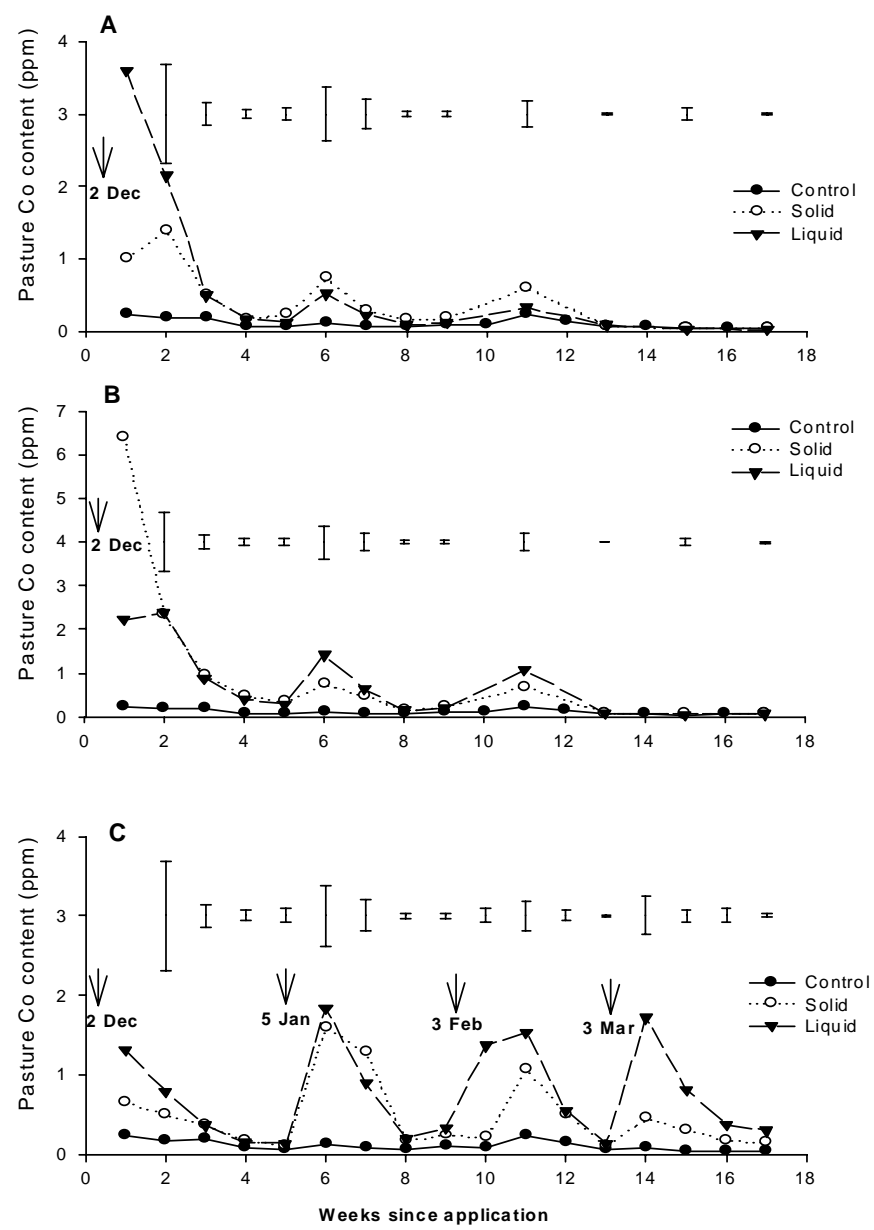

increase in pasture $\mathrm{Cu}$ over control in December, both forms had pasture $\mathrm{Cu}$ significantly greater than control in January (up to 3 weeks after application), and liquid application also resulted in significantly higher pasture $\mathrm{Cu}$ than solid application for up to 2-3 weeks after application in February and March.

\section{Rainfall}

Rainfall in the week following each application date was $15.1 \mathrm{~mm}$ in December, $1.5 \mathrm{~mm}$ in January, $40.5 \mathrm{~mm}$ in February and $13.5 \mathrm{~mm}$ in March. Monthly rainfall was $105 \mathrm{~mm}$ in December, $87 \mathrm{~mm}$ in January, $66 \mathrm{~mm}$ in February and $58 \mathrm{~mm}$ in March.

\section{Discussion}

The 7-week duration of effect of the single application of $240 \mathrm{~g} \mathrm{CoSO}_{4} / \mathrm{ha}$ applied as liquid was similar to that reported by Metherell (1989) at the same rate on the 
Figure 2 Effect of solid and liquid $\mathrm{CuSO}_{4}$ on pasture $\mathrm{Cu}$ content for (A) $5 \mathrm{~kg} / \mathrm{ha}$ applied once, (B) $10 \mathrm{~kg} / \mathrm{ha}$ applied once, and (C) $1.25 \mathrm{~kg} / \mathrm{ha}$ applied monthly. Bars are LSD (5\%). Arrows indicate application dates.
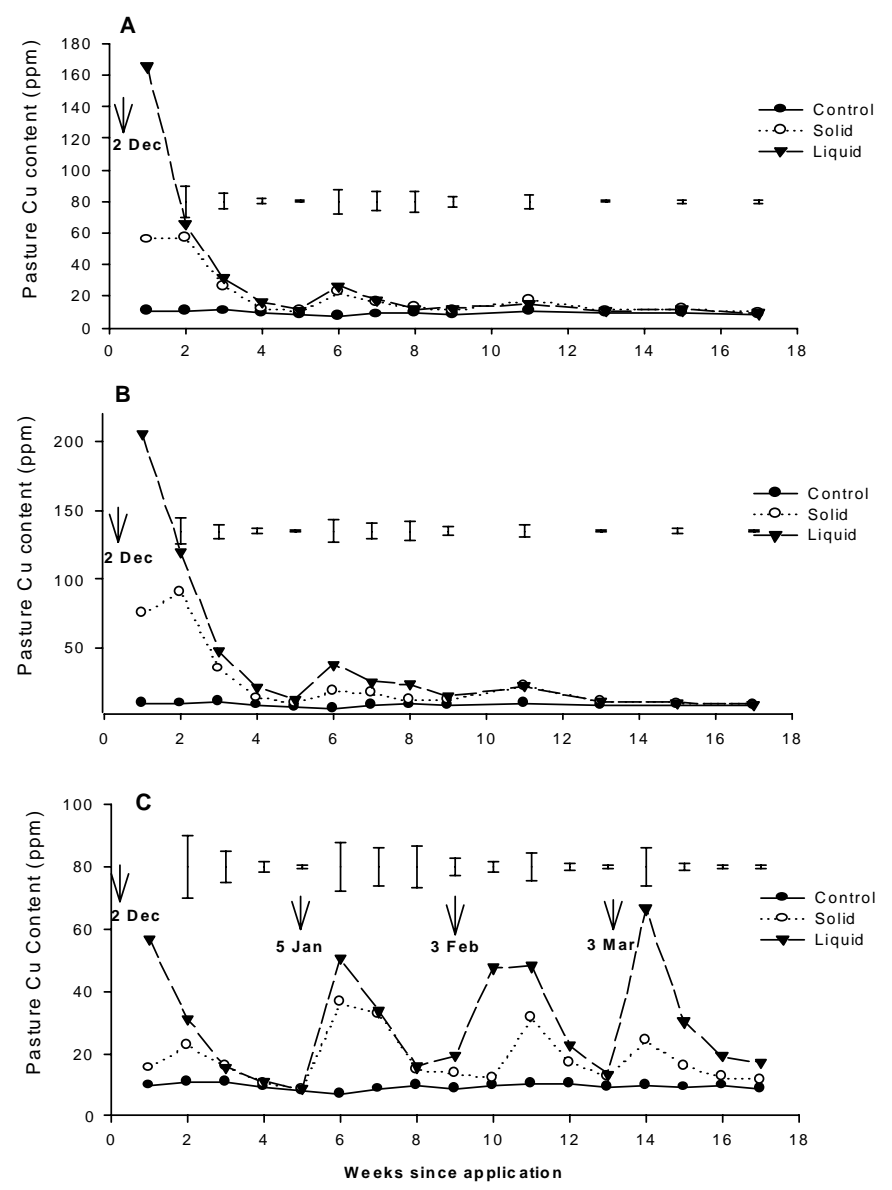

at both 5 and $10 \mathrm{~kg} / \mathrm{ha}$ was much shorter than the 6-month duration reported by Morton (unpublished results) on pumice soils where the same rates of $\mathrm{CuSO}_{4}$ were applied. In contrast, the effect in our trial peaked at a $16-(5 \mathrm{~kg} / \mathrm{ha})$ to 20 -fold (10 kg/ha) increase over control compared with a 1.5- to 3-fold increase reported by Morton (unpublished results). This indicates that there may have been a trade-off between the duration and size of the effect at these sites.

The advantage of monthly applications of liquid over solid $\mathrm{CoSO}_{4}$ in February and March but not January was also reported by Pringle et al. (2000). There are three possible mechanisms by which application in the liquid form could result in higher pasture Co content than from the solid form. The liquid $\mathrm{CoSO}_{4}$ could be absorbed through the leaf, it could adhere to the leaf, or could be dispersed more effectively in the soil to be taken up by roots, especially at low soil moisture content. It is assumed that all of the solid $\mathrm{CoSO}_{4}$ falls through the pasture canopy and can only be taken up by plant roots. Plants may take up Co through the leaf, however Co taken up this way is practically immobile (Gustafson \& Schlessinger 1956) but still could be available to the animal. Root uptake of nutrients is usually much greater than foliar absorption. Rainfall

Waikiwi brown soil at Woodlands Research Station. On a Southland pallic soil, 175 and $350 \mathrm{~g} \mathrm{CoSO}_{4} /$ ha applied as liquid also increased pasture Co content for 8 weeks but for less than 4 weeks when applied in the solid form (Pringle et al. 2000). Sherrell (1990) measured a shorter duration of 4 weeks to a lower application rate of $40 \mathrm{~g} \mathrm{CoSO}_{4} / \mathrm{ha}$ in both solid and liquid form on an allophanic soil. The peak size of the liquid form effect ranged from 6 times (Sherrell 1990; Pringle et al. 2000) to 100 times (Metherell 1989) that of control, compared with 10 times in our trial. In the solid form, the peak effect varied from 2-3 times (Sherrell 1990; Pringle et al. 2000) that of control, compared with $4\left(120 \mathrm{~g} \mathrm{CoSO}_{4} / \mathrm{ha}\right)$ to 28 times $(240 \mathrm{~g}$ $\mathrm{CoSO}_{4} / \mathrm{ha}$ ) in our trial. These results suggest that the duration and size of the increase in pasture Co will differ between soil types and years.

The duration of effect of December applications of solid forms of $\mathrm{CuSO}_{4}$ of 3 and 5 weeks respectively in the week after each application was greater than $12 \mathrm{~mm}$ in all months except January, presumably sufficient to wash the soluble $\mathrm{CoSO}_{4}$ off the leaf before the first sampling. There was no significant difference in pasture Co content between forms at the first sampling after the January application indicating that adherence of liquid $\mathrm{CoSO}_{4}$ to the leaf did not occur. The better coverage of liquid $\mathrm{CoSO}_{4}$ on the surface resulting in improved dispersion in the soil is a possible mechanism, as at $60 \mathrm{~g} / \mathrm{ha}$, there were only 126 grains/ $\mathrm{m}^{2}$ applied as solid $\mathrm{CoSO}_{4}$. Monthly rainfall did decline from December to March so soil moisture could have limited movement of Co to plant roots in February and March, resulting in an advantage to the liquid form. Lower soil moisture in February and March could also have reduced pasture uptake of soil Co in a situation where soil Mn levels were high (Zheng Li et al. 1999). Even if the mechanism for the higher pasture content from the liquid form could not be 
clearly identified in this trial, the results indicate that application of liquid $\mathrm{CoSO}_{4}$ and $\mathrm{CuSO}_{4}$ is more effective than solid in months with lower rainfall. For $\mathrm{Cu}$, where the effect of form was similar to Co, most of these factors should apply. However improved coverage $\left(800\right.$ grains $\left./ \mathrm{m}^{2}\right)$ from the higher rate of monthly applied solid $\mathrm{CuSO}_{4}(1.25 \mathrm{~kg} / \mathrm{ha})$ would have been expected to reduce the effect of liquid application increasing dispersion of $\mathrm{Cu}$ in the soil.

The peak in pasture $\mathrm{Co}$ and $\mathrm{Cu}$ at 1 week after monthly application also suggests that for maximum intake by grazing animals, grazing should be carried out at this time. This may mean that application may need to be carried out 2-3 weeks after the previous grazing if the interval between grazings is 4 weeks. Application of high rates of $\mathrm{CuSO}_{4}$ in both forms elevated pasture $\mathrm{Cu}$ well above the lower end of the toxic range for sheep (20 ppm) for 2-3 weeks after application so sheep should be withheld from pasture where $\mathrm{Cu}$ has been applied for that period.

It must be acknowledged that the effects of the treatments were not measured in terms of animal trace element concentrations. The relationship between pasture and animal trace element status can be confounded by factors such as soil intake of trace elements and the effect of animal molybdenum intake on $\mathrm{Cu}$ availability. Any extrapolation of pasture trace element uptake results must take these factors into consideration.

\section{Conclusions}

1. High rates of solid (240 kg/ha) and liquid (120 and $240 \mathrm{~g} / \mathrm{ha}) \mathrm{CoSO}_{4}$ and solid and liquid $\mathrm{CuSO}_{4}(5$ and $10 \mathrm{~kg} / \mathrm{ha}$ ) applied in early December only elevated pasture $\mathrm{Co}$ and $\mathrm{Cu}$ content for 2-8 weeks after application. Therefore, if required, high rates of $\mathrm{CoSO}_{4}$ and $\mathrm{CuSO}_{4}$ should be used at a time (late spring for $\mathrm{Co}$, autumn for $\mathrm{Cu}$ ) that enables lambs $\mathrm{Co}$ and cattle and deer $(\mathrm{Cu})$ to build up liver stores before critical periods.
2. Monthly applications of solid and liquid $\mathrm{CoSO}_{4}$ $(60 \mathrm{~g} / \mathrm{ha})$ and $\mathrm{CuSO}_{4}(1.25 \mathrm{~kg} / \mathrm{ha})$ elevated pasture $\mathrm{Co}$ and $\mathrm{Cu}$ for up to 3 weeks when applied in early January, February and March but not early December for $\mathrm{CoSO}_{4}$. Liquid applications were more effective than solid applications in February and March. In summer/autumn months with lower rainfall, $\mathrm{CoSO}_{4}$ and $\mathrm{CuSO}_{4}$ if required, should be applied in the liquid form and the pasture grazed 1 week after application for maximum animal intake.

\section{ACKNOWLEDGEMENTS}

The authors thank Beth Henderson and Fairlie Sim for assisting with the measurements and SouthFert for funding the trial.

\section{REFERENCES}

Gustafson, F.G.; Schlessinger, M.J. 1956. Absorption of ${ }^{60} \mathrm{Co}$ by bean plants in the dark. Plant Physiology 31: 316-318.

Metherell, A.K. 1988. The cobalt enigma - some observations for Otago and Southland. Proceedings of the New Zealand Grassland Association 50: 101108.

Pringle, G.; Beckingsale, B; Metherell, A.K. 2000. Onfarm evaluations of cobalt/vitamin $\mathrm{B}_{12}$ supplementation for lamb growth on southern South Island properties. Proceedings of New Zealand Grassland Association 62: 33-38.

Sherrell, C.G. 1990. Effect of cobalt application on the cobalt status of pastures. 3. Comparison of chelate and sulphate as cobalt sources for topdressing deficient pastures. New Zealand Journal of Agricultural Research 33: 313-317.

Zheng Li; McLaren, R.G.; Metherell, A.K. 1999. The effects of soil manganese status on the bioavailability of soil cobalt for pasture uptake in New Zealand soils. Proceedings of the New Zealand Grassland Association 61: 133-137. 